\title{
Determination of uric acid levels in uraemia by enzymatic and colorimetric techniques
}

\author{
P. J. N. HOWORTH AND JOAN F. ZILVA \\ From the Department of Chemical Pathology, Westminster Medical School, London
}

SYNOPSIS Serum uric acid levels were determined by specific and non-specific methods in uraemia in order to investigate the correlation between non-specific chromogen and serum urea level. The correlation was moderate and the magnitude of the non-specific chromogen was smaller than had been reported previously. The ratio True urate was found to be 0.85 in both acute and chronic renal failure, a ratio very similar to that previously reported for normal and gouty subjects.

In chronic renal failure the true uric acid level is correlated with urea level and there is a suggestion that serum uric acid levels in chronic renal failure are lower for a given urea value than in acute renal failure.

It is well known that, within the normal range, uric acid estimation by a specific uricase method gives a result up to $1 \mathrm{mg} / 100 \mathrm{ml}$ lower than by the non-specific Folin phosphotungstate method (Wolfson, Huddlestun, and Levine, 1947; Henry, Sobel, and Kim, 1957). Wolfson et al. stated that not only in normals, but also in gout 'the proportion of total urate formed by true urate is so regular that it may be safely estimated by a conversion factor', found to be $0 \cdot 85-0 \cdot 90$. In the presence of uraemia, on the other hand, non-specific chromogens and true uric acid might be retained in different proportions. Gross and Bolliger (1957) studied 11 patients with renal insufficiency and found that over a blood urea range of 150 to $590 \mathrm{mg} / 100 \mathrm{ml}$ the discrepancy varied between 0.6 and $7.9 \mathrm{mg} / 100 \mathrm{ml}$. In a single fatal case of eclampsia (blood urea value not stated) a difference of as much as $15 \mathrm{mg} / 100 \mathrm{ml}$ was found.

Sincemany hospital laboratories use a Folin method rather than a uricase method on grounds of convenience and expense, and since with the advent of allopurinol treatment of gout the actual level of uric acid in uraemia has become of greater importance, it was felt desirable to compare results of uric acid estimation in uraemia by both techniques with a view to assessing the reliability of the Folin method in this condition.

\section{MATERIALS AND METHODS}

Sera sent to the laboratory for routinechemical pathological Received for publication 20 July 1967. tests were analysed as available. Serum urea was determined by a standard diacetyl monoxime procedure (AutoAnalyzer,Technicon).Serum uricacid was determined by both a standard modification of the Folin phosphotungstate method (Henry et al., 1957) and a uricase method (Wootton, 1964), the readings in each case being made on the same instrument (Hilger Uvispek).

Fifty-two pairs of uric acid estimations were made on sera taken on diferent days from 26 patients with acute or chronic renal failure, and a further nine pairs on nine patients with miscellaneous medical or surgical conditions, all having a serum urea level of greater than $100 \mathrm{mg} / 100 \mathrm{ml}$. Uric acid determinations were made in duplicate whenever sufficient serum was available ( $50 \%$ of cases).

The precision of the phosphotungstate and uricase methods used was determined by analysis of differences in duplicates (Table I). The sera used included 10 from patients with serum urea levels of less than $100 \mathrm{mg} / 100 \mathrm{ml}$.

TABLE I

PRECISION OF THE METHODS FOR ESTIMATION OF SERUM URIC ACID

Serum Uric Acid

Phosphotungstate Uricase Method

Method

\begin{tabular}{lcc}
\hline No. of duplicates & 41 & 31 \\
Mean uric acid & 9.6 & 8.9 \\
Standard deviation & 0.67 & 0.67 \\
Coefficient of variation (\%) & 7.0 & 7.6
\end{tabular}

RESULTS

The results of the analyses on the 61 uraemic sera are given graphically. In Figure 1 the true uricase 


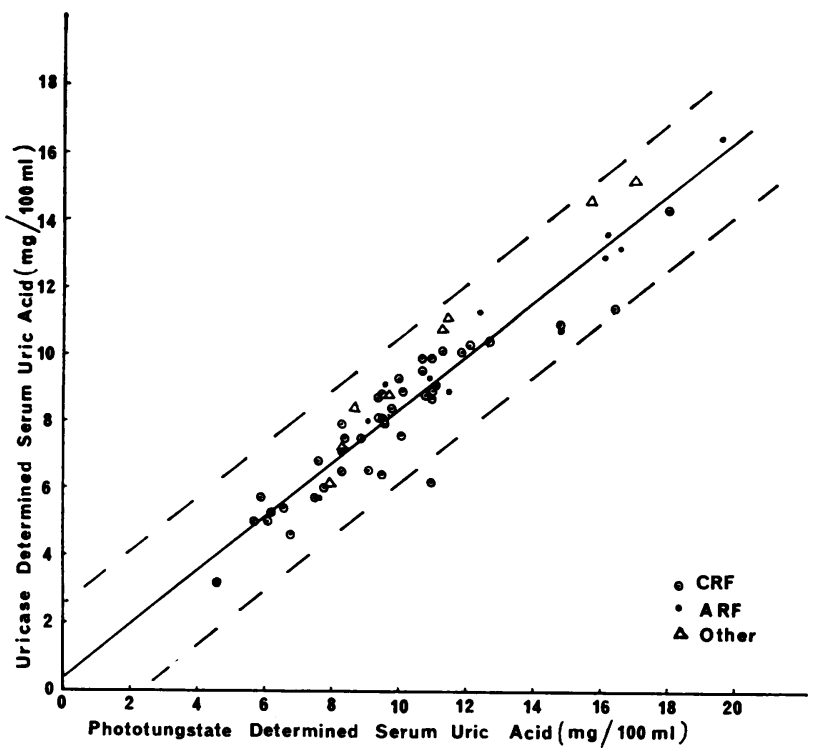

FIG. 1. Uricase-determined serum uric acid levels plotted against phosphotungstate-determined serum uric acid levels. The calculated regression line is shown (solid line) and confidence limits are placed at two standard errors of estimate $(\mathrm{Sy})$. $y=0.808 x+0.29 ; S y=0.866$ $r=0.949, \mathrm{P}<0.001$

A.R.F. = acute renal failure, C.R.F. = chronic renal failure

determined serum uric acid is plotted against the phosphotungstate determined value for the same serum. The correlation coefficient, $r$, was $0.949(\mathrm{P}<$ 0.001 ). The calculated $95 \%$ control limits are shown on either side of the regression line.

Figure 2 shows the differences between the phosphotungstate and uricase uric acid values (range 0.1-5.0 $\mathrm{mg} / 100 \mathrm{ml}$ ) plotted against serum urea (range $100-692 \mathrm{mg} / 100 \mathrm{ml}$ ). The correlation coefficient, $r$, was $0.576(P<0.001)$. The calculated
$95 \%$ confidence limits are shown on either side of the regression line. There was, as expected, a positive correlation between true serum uric acid and serum urea levels in chronic renal failure; the data are given in Figure 3. The correlation coefficient, $r$, was $0.638(\mathrm{P}<0.001)$. The calculated regression line is shown and the regression line from Figure 2 has been 'included' to indicate the average error of the phosphotungstate method at any urea level in chronic renal failure. There were not enough data

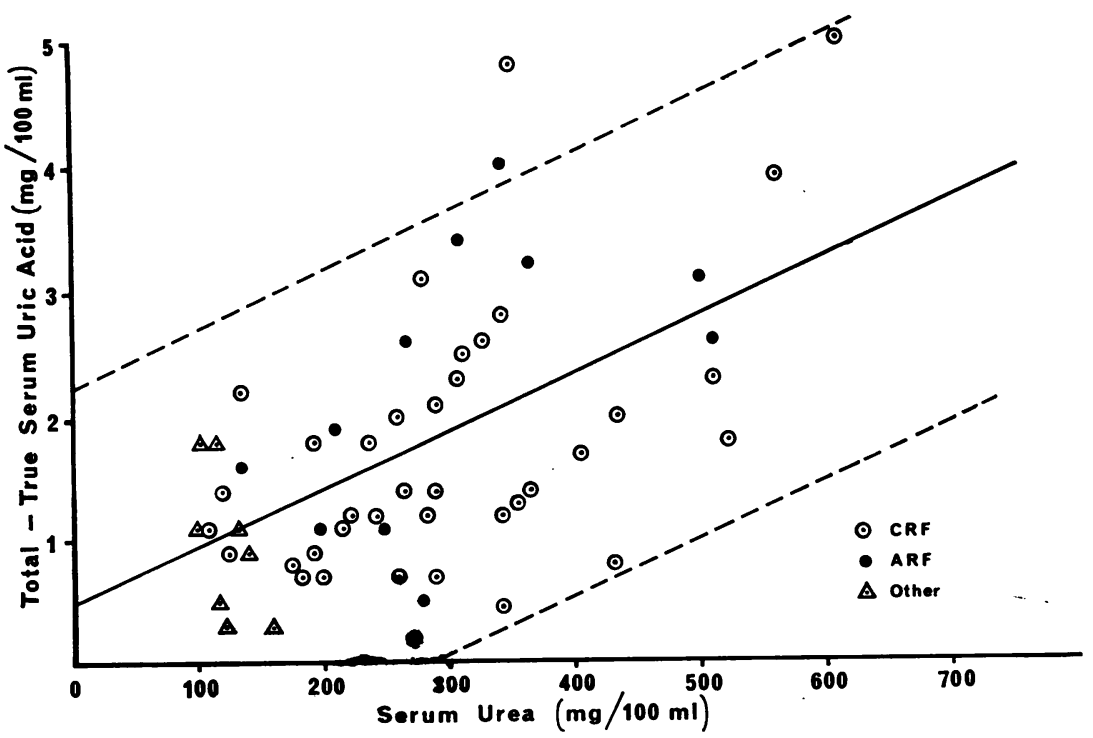

FIG. 2. Difference between phosphotungstate and uricase serum uric acid levels plotted against serum urea, with confidence limits placed at two standard errors of estimate $(S y)$ on either side of the regression line. $y=0.00465 x+0.463$; $\mathrm{Sy}=0.982$ $r=0.576, \mathrm{P}<0.001$. 


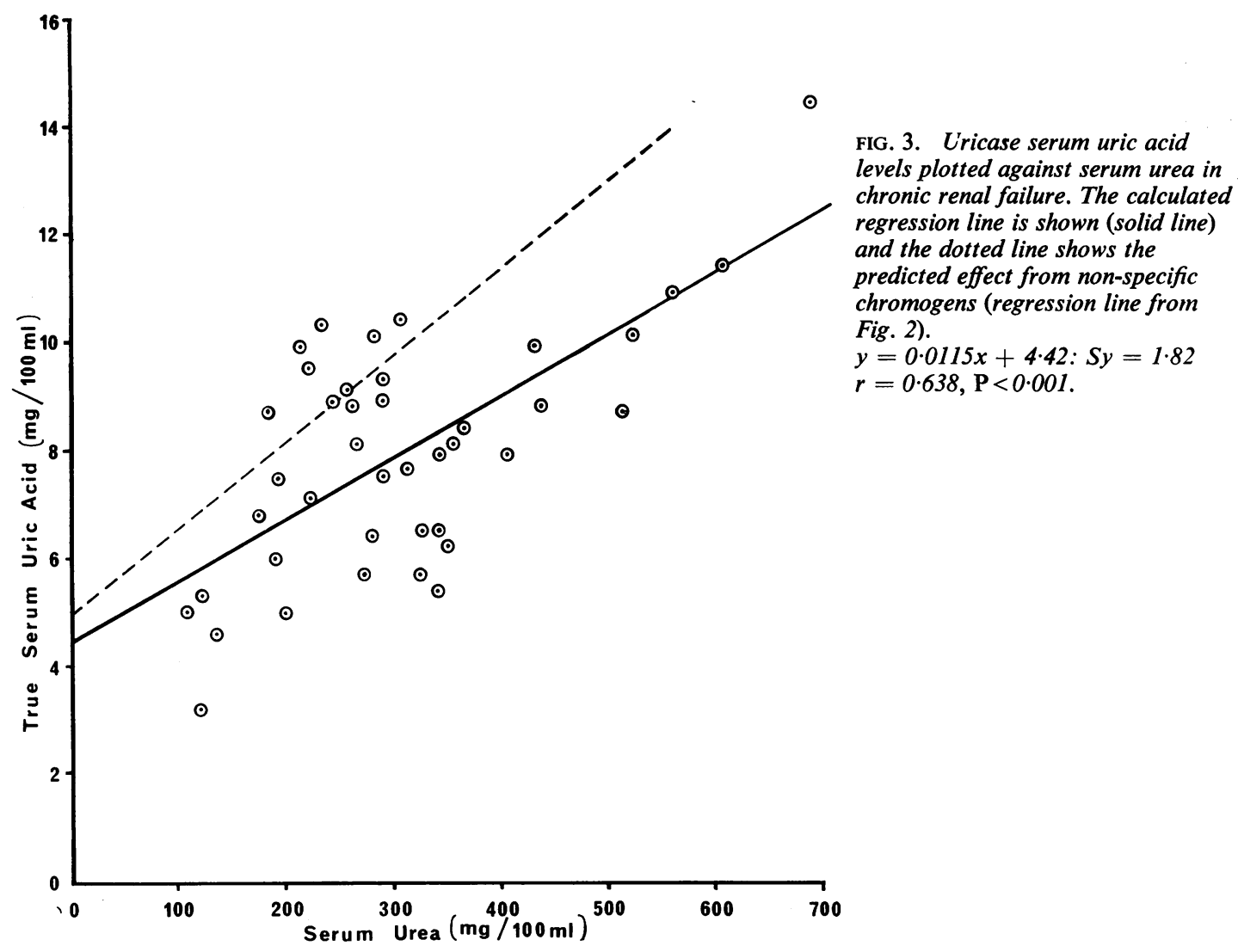

for a similar comparison in acute renal failure, but results in Table II suggest that the situation is much the same as that in chronic renal failure.

\section{TABLE II}

SERUM URIC ACID LEVELS IN ACUTE AND CHRONIC RENAL FAILURE AND OTHER URAEMIC CONDITIONS

\begin{tabular}{|c|c|c|c|c|}
\hline & \multirow{2}{*}{$\begin{array}{l}\text { Mean Serum } \\
\text { Urea Con- } \\
\text { centration } \\
(\mathrm{mg} / 100 \mathrm{ml})\end{array}$} & \multicolumn{2}{|c|}{$\begin{array}{l}\text { Mean Serum Uric } \\
\text { Acid Concentration } \\
(\mathrm{mg} / 100 \mathrm{ml})\end{array}$} & \multirow[t]{2}{*}{$\begin{array}{l}\text { Ratio True: } \\
\text { Total Urate }\end{array}$} \\
\hline & & $\begin{array}{l}\text { Phospho- } \\
\text { tungstate } \\
\text { Method }\end{array}$ & $\begin{array}{l}\text { Uricase } \\
\text { Method }\end{array}$ & \\
\hline $\begin{array}{l}\text { Acute renal failure } \\
(\mathrm{n}=11)\end{array}$ & 307 & $13 \cdot 1$ & 10.9 & 0.83 \\
\hline $\begin{array}{l}\text { Chronic renal failure } \\
(n=41)\end{array}$ & e 308 & $9 \cdot 7$ & 8.0 & 0.83 \\
\hline Other $(n=9)$ & 121 & $11 \cdot 2$ & $10 \cdot 1$ & 0.90 \\
\hline
\end{tabular}

DISCUSSION

In view of the increasing significance attached to knowledge of true uric acid levels in renal failure and of reports of high values of uricase-resistant chromogen in uraemia (Gross and Bolliger, 1957; Yü and Gutman, 1957), it seemed important to determine the magnitude of our laboratory error on sera with high blood urea levels.

The amount of non-specific chromogen is still a matter of some dispute, possibly because workers used different modifications of Folin's original phosphotungstate method (1933). We use that of Henry et al. (1957) which has been shown to correlate well with the uricase method. Figure 1 shows that even with high serum uric acid levels this relation continues to hold good. An average of $11 \%$ of total chromogen is due to uricase-resistant substances, so that the urate value obtained by the Folin method should be multiplied by a factor of 0.8 to 0.9 to give true uric acid values. Our value for this factor (Table II) agrees closely with this figure and with that shown by Wolfson et al. (1947) of 0.85 to 0.9 even at the high serum urea levels of our series. At the upper end of the normal range the difference is approximately $1 \mathrm{mg} / 100 \mathrm{ml}$. 
TABLE III

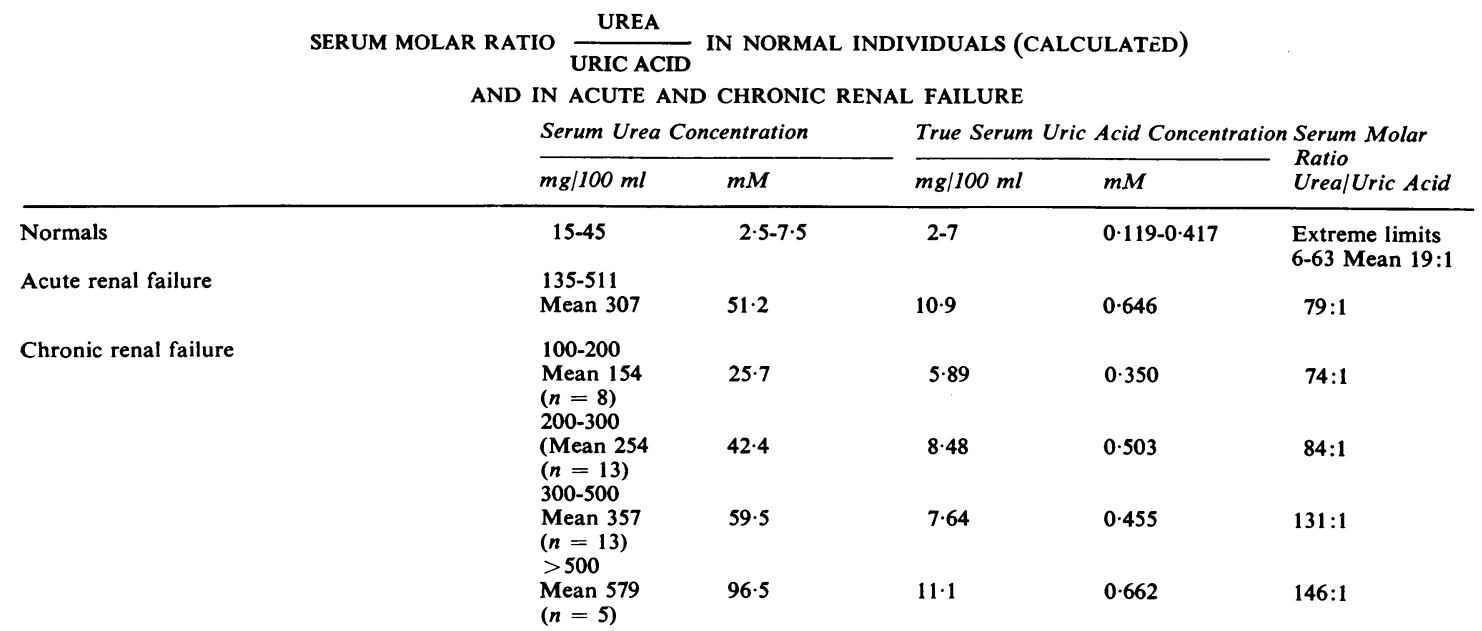

Figure 2 shows that apart from a few outliers, there is a moderate correlation between the concentration of non-specific chromogen and serum urea. The mean level of $1.75 \mathrm{mg} / 100 \mathrm{ml}$ chromogen at a mean urea level of $285 \mathrm{mg} / 100 \mathrm{ml}$ indicates that in most uraemic patients the use of a reliable phosphotungstate method will not cause serious error: only in the rare situation of a urea level of more than 500 $\mathrm{mg} / 100 \mathrm{ml}$ does the mean level of chromogen reach $3 \mathrm{mg} / 100 \mathrm{ml}$. At such a urea level in chronic renal failure the true uric acid will be about $10 \mathrm{mg} / 100 \mathrm{ml}$ (Figure 3), but the assumption that $1020 \%$ of a phosphotungstate value obtained in such circumstances is due to chromogen will give a corrected figure not far from the true one.

Figure 3 also shows that in chronic renal failure the true serum uric acid level correlates fairly closely with that of the serum urea, rising to double its mean normal value at a urea concentration of about $400 \mathrm{mg} / 100 \mathrm{ml}$. This slow rise in uric acid compared with urea is also demonstrated in Table III which shows the relatively lower serum molar ratio

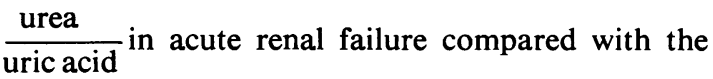
ratio in chronic renal failure at similar urea levels. This may be due to the uric acid clearance falling more slowly than urea clearance, or to inhibition of purine synthesis. We have no evidence to support either view

The data do not support the findings of Johnstone (1952) who reported lack of correlation between total uric acid and non-specific chromogen. We agree with Wolfson et al. (1947) who found a constant relationship between true and total 'urate' in plasma and urine from normal and gouty subjects and the data presented in this paper suggest that this relationship holds true also in uraemic serum.

We do not agree with the view expressed by Hansen (1967) that 'none of the colorimetric methods is satisfactory and comparison of the values obtained in different laboratories has shown wide discrepancies'. On the contrary, in a survey of 36 laboratories in the United Kingdom (Bywaters and Holloway, 1964) it was found that the scatter of results with uricase techniques was as great as that with colorimetric manual methods, and it was concluded that, for technical reasons, the method of choice for routine use was still that of Folin (1930) preferably modified for use on the AutoAnalyzer.

Thus there seems no real contraindication to the use of a reliable phosphotungstate method for uric acid estimation, even in the presence of uraemia, with the use of a correction factor of about 0.85 to give the true serum uric acid level.

\section{REFERENCES}

Bywaters, E. G. L., and Holloway, V. P. (1964). Ann. rheum. Dis. $23,236$.

Folin, O. (1930). J.biol. Chem., 86, 179.

- (1933). Ibid., 101, 111.

Gross, R., and Bolliger, A. (1957). Aust. Ann. Med., 6, 64.

Hansen, O. E. (1967). Lancet, 1, 396.

Henry, R. J., Sobel, C., and Kim, J. (1957). Amer. J. clin. Path., 28,152. Johnstone, J. M. (1952). J. clin. Path., 5, 317.

Wolfson, W. Q., Huddlestun, B., and Levine, R. (1947). J. clin. Invest., 26, 995.

Wootton, I. D. P. (1964). Micro-analysis in Medical Biochemistry, 4th ed., p 86. Churchill, London. Yü, T. F., and Gutman, A. B. (1957). Bull. rheum. Dis. (Suppl.) 